\title{
BLOK PERIODIZACIJA - PREKRETNICA ILI ZABLUDA U SPORTSKOM TRENINGU
}

\author{
Vladimiri Koprivica
}

${ }^{1}$ Fakultet sporta i fizičkog vaspitanja, Univerzitet u Beogradu, Srbija

\section{SAŽETAK}

Blok periodizacija se javila kao nova ideja u pripremi sportista. $\mathrm{Na}$ osnuvu analize tradicionalne teorije sportskog treninga i njenog segmenta, periodizacije treninga tokom takmičarske sezone, pobornici blok periodizacije su iznijeli niz primjedbi. Osnovni zaključak je da klasična periodizacija više ne odgovara zahtijevima savremenog sporta jer se raširio kalendar takmičenja. Klasična periodizacija se zasniva na istovremenom razvoju više sposobnosti u dužem pripremnom periodu i velikim obimima rada. To ometa sportiste da uspješno učestvuju na više takmičenja tokom sezone. Ipak, po mišljenju pobornika blok periodizacije, ovo se odnosi samo na vrhunske sportiste.

Sa druge strane, postoji niz primjedbi na opravdanost i logiku blok periodizacije. Termin "blok periodizacija" nije adekvatan, a kritika klasične teorije je metodološki pogrešna jer se odnosi na stare bibliografske izvore, prećutkuju se neistomišljenici. Nije realno u praksi da se radi sukcesivno na više sposobnosti jer su skraćeni periodi pripreme, nije dovoljno vremena za oporavak poslije takvih napora i znatno je veći rizik od povređivanja. Najvažnije je da je po blok periodizaciji teško biti u formi u pravo vrijeme što je osnovni smisao periodizacije. Zato bi se prije moglo reći da je blok periodizacija zabluda, a ne prekretnica u treningu.

Ključne riječi: blok periodizacija, teorija sportskog treninga, vrhunski sportisti, sportska forma.

Teorija sportskog treninga je nastajala postepeno na osnovu praktičnog iskustva koje se ubrzano nagomilavalo od kada su obnovljene Olimpijske igre. Sport je sa godinama dobijao na svom društvenom značaju, naročito poslije Drugog svjetskog rata. Postignuti rezultati su bili ne samo mjerilo mogućnosti čovjeka, već i sredstvo promocije društveno-ekonomskih sistema, pa i sistema pripreme sportista za najvažnija takmičenja. Sistem pripreme je, u početku, u velikoj mjeri zavisio od sezonsko-klimatskih uslova, od godišnjeg doba i kalendara takmičenja. U vezi sa tim, 60-tih godina počelo se govoriti o problemu periodizacije sportskog treninga, kao važnom segmentu teorije i prakse sportskog treninga.

Podjela na periode nije ništa novo, jer su ljudi u svakoj aktivnosti to oduvijek činili, ali je periodizacija sportskog treninga tokom godine, sa ciljem da se postignu najbolji rezultati u vrijeme takmičenja bila relativno nova ideja. U početku se smatralo da periodizacija zavisi od sezonsko-klimatskih uslova i kalendara takmičenja. Međutim, sve obimnije i sadržajnije analize takmičarske stvarnosti dovele su do ozbiljnih teorijskih postavki, pa i do nivoa teorije periodizacije koju je, oslanjajući se na brojne prethodnike, formirao i naučno objasnio Матвеeв $(1964,1977)$. On je dokazao da osnovu periodizacije čine zakonomjernosti procesa razvoja sportske forme i da periodizacija u suštini predstavlja upravljanje tim procesom.

Matvejev je u toj oblasti postao takav autoritet da je njegovo ime postalo sinonim za teoriju periodizacije sportskog treninga. Zato se u brojnim radovima, koji se bave problemom periodizacije, ova teorija često naziva "teorija Matvejeva". S obzirom da ona kao aktuelna teorija traje skoro pola vijeka, sve češće se označava kao "tradicionalna teorija periodizacije" ili "tradicionalna teorija periodizacije Matvejeva".

Teorija sportskog treninga je nastajala postepeno na osnovu praktičnog iskustva koje se ubrzano 
nagomilavalo od kada su obnovljene Olimpijske igre. Sport je sa godinama dobijao na svom društvenom značaju, naročito poslije Drugog svjetskog rata. Postignuti rezultati su bili ne samo mjerilo mogućnosti čovjeka, već i sredstvo promocije društveno-ekonomskih sistema, pa i sistema pripreme sportista za najvažnija takmičenja. Sistem pripreme je, u početku, u velikoj mjeri zavisio od sezonsko-klimatskih uslova, od godišnjeg doba i kalendara takmičenja. U vezi sa tim, 60-tih godina počelo se govoriti o problemu periodizacije sportskog treninga, kao važnom segmentu teorije $i$ prakse sportskog treninga.

Podjela na periode nije ništa novo, jer su ljudi u svakoj aktivnosti to oduvijek činili, ali je periodizacija sportskog treninga tokom godine, sa ciljem da se postignu najbolji rezultati u vrijeme takmičenja bila relativno nova ideja. U početku se smatralo da periodizacija zavisi od sezonsko-klimatskih uslova i kalendara takmičenja. Međutim, sve obimnije i sadržajnije analize takmičarske stvarnosti dovele su do ozbiljnih teorijskih postavki, pa i do nivoa teorije periodizacije koju je, oslanjajući se na brojne prethodnike, formirao i naučno objasnio Матвеeв $(1964,1977)$. On je dokazao da osnovu periodizacije čine zakonomjernosti procesa razvoja sportske forme i da periodizacija u suštini predstavlja upravljanje tim procesom.

Matvejev je u toj oblasti postao takav autoritet da je njegovo ime postalo sinonim za teoriju periodizacije sportskog treninga. Zato se u brojnim radovima, koji se bave problemom periodizacije, ova teorija često naziva "teorija Matvejeva". S obzirom da ona kao aktuelna teorija traje skoro pola vijeka, sve češće se označava kao "tradicionalna teorija periodizacije" ili "tradicionalna teorija periodizacije Matvejeva".

Prve ozbiljnije kritike ove teorije pojavile su se oko 1990. godine i razbuktale poslednjih godina prošlog vijeka. U najvažnijem časopisu u Rusiji (Теория u ирактика физической культурьъ) vođena je velika polemika između najvećih autoriteta u ovoj oblasti. Neki autori su oštro napali osnovne postavke važeće teorije, dok su ih drugi autori energično branili. Svakako najveći kritičar i najveće ime među protivnicima bio je J. V. Verhošanski. On i nekoliko njegovih istomišljenika iznijeli su niz kritičkih stavova na račun teorije Matvejeva. U okviru kritike cjelokupne teorijske osnove važeće teorije sportskog treninga postavilo se pitanje periodizacije u toku godine. Nasuprot klasičnoj periodizaciji predložena je tzv. "blok periodizacija", koja je kao ideja nastala između 1970. i 1980. godine, a kasnije sve je više promovisana u radovima Verhošanskog $\mathrm{i}$ njegovih sljedbenika. "Blok sistem - to je netradicionalni oblik organizacije trenažnog procesa u godišnjem ciklusu, predviđen isključivo za vrhunske sportiste, kako u amaterskom, tako i u profesionalnom sportu" (Верхошанский, 2005). Ova ideja najcjelovitije je razrađena u knjizi V. Issurina (2008) na engleskom jeziku pod nazivom "BLOCK PERODIZATION: BREAKTHROUGH IN SPORTS TRAINING". Knjiga je prevedena na više jezika, a pojavila se i u prevodu na srpski jezik (Issurin, 2009).

Šta pobornici nove, blok periodizacije, zamjeraju tradicionalnoj teoriji sportskog treninga i u čemu vide prednost novog pristupa koji predlažu u pripremi sportista?

Prvo treba istaći da blok periodizacija ne negira u potpunosti vrijednosti tradicionalne periodizacije. Issurin (2009) ističe: "Tradicionalni pristup je i dalje pogodan za standardne, ali ne i za vrhunske sportiste", pa se sve primjedbe upućene teoriji Matvejeva odnose samo na ovaj segment sporta.

Osnovne razloge zbog kojih je tradicionalna periodizacija sportskog treninga neodrživa u treningu vrhunskih sportista, oponenti svode na sledeće:

- poslednjih decenija dramatično je povećan broj takmičenja i povećani su sportski rezultati;

- znatno je smanjen ukupan obim trenažnog rada;

- pojavili su se novi pojmovi koji utiču na planiranje i kreiranje alternativne periodizacije treninga.

Klasična periodizacija ima niz nedostataka koji obuhvataju (Issurin, 2009):

- ograničenja nastala istovremenim razvojem brojnih motoričkih i tehničkih sposobnosti;

- nemogućnost obezbjeđivanja pripreme za više glavnih takmičenja, odnosno uspješnog učešća na mnogim takmičenjima;

- preduge periode osnovne pripreme i pripreme za određeni sport.

U obimnom radu u kome detaljno obrazlaže potrebu da se u praksi primjeni blok periodizacija, Верхошанский (2005) ukazuje da su ranije analize priprema sovjetskih sportista otkrile niz nedostataka i negativnih tendencija. Sve je uslovljeno "[...] niskim naučno-teorijskim i metodičkim nivoom korišćene koncepcije periodizacije treninga". U radu sa vrhunskim sportistima griješilo se u sljedećem:

- u godišnjem ciklusu haotično su se koristila i relativno ravnomjerno rasporedivala opterećenja različite usmjerenosti;

- vježbe sa teretom su se uglavnom koristile nespecijalizovano i nesistematično za razvoj sile i kao dodatno sredstvo za rješavanje glavnih zadataka treninga;

- u mikrociklusu su neopravdano korišćena sredstva sa izrazito velikim obimom, što je narušavalo sintezu bjelančevina koja je osnovna komponenta 
adaptacije;

- opšta tendencija da se poveća sumarni obim opterećenja postala je sama sebi cilj.

"Sve te tendencije su imale isti uzrok - kompleksnoparalelnu formu organizacije trenažnih opterećenja [...]", a treneri su se u praksi rukovodili parolom: "Ako hoćeš da pobijediš protivnika - treba da treniraš više od njega" (Верхошанский, 2005).

Issurin (2009) navodi da "Nasuprot tradicionalnom modelu, pojam blok periodizacije karakterišu sledeće prednosti:

- ukupan obim trenažnog rada može se znatno smanjiti, čime se takođe smanjuje rizik od nastanka pretreniranosti sportiste;

- trenažni plan koji predviđa više maksimalnih takmičarskih nastupa omogućava i ujedno olakšava uspješno učešće na brojnim takmičenjima tokom čitave sezone;

- praćenje i kontrola pripremljenosti mogu biti efikasni jer se svako drastično smanjenje neke od sposobnosti sportiste može procijeniti u svakom mezociklusu;

- ishrana i program oporavka sportiste mogu se adekvatno mijenjati u zavisnosti od preovlađujućeg tipa treninga, $\mathrm{i}$

- godišnji plan koji obuhvata više trenažnih faza omogućava povoljnije uslove za ostvarenje maksimalnih postignuća u vrijeme glavnog takmičenja u sezoni."

Ako bi uvažili misao velikog pisca Borhesa da knjiga koja nema protivknjigu smatra se nekompletnom, možda bi to mogli reći i za svaku teoriju. Zato autorima koji su izmislili blok periodizaciju i kritički se osvrnuli na klasičnu teoriju periodizacije, treba odati priznanje. To je prije svega Verhošanski čija je kritika izazvala brojne autore da o problemu periodizacije polemišu u značajnom časopisu, Теория и практика физической кyльтуры (Moskva). Ipak, svima koji su kritikovali klasičnu teoriju periodizacije može se zamjeriti zbog više propusta koji nisu promakli autorima koji su stali u odbranu klasične teorije:

1. Termin "blok" je veoma problematičan kada se stavi u ravan sa drugim terminima koji su već duže u upotrebi: ciklus, period, etapa ili faza. Ciklus čini jednu osmišljenu, izgrađenu i zaokruženu radnu cjelinu sa svim, u njoj međusobno povezanim, procesima. Period je vremenski ograničena cjelina u sezoni u kojoj je akcenat na usavršavanju nekog procesa, dok je etapa i faza dio tog procesa. Ovi termini odražavaju suštinu procesa takmičenja i pripreme sportista tokom sezone. Termin "blok" nije termin vezan za vrijeme i njime se ne može označiti vremenski period u kome se odvija neki takmičarski ili trenažni proces. On se prije može koristiti za obeležavanje neke male cjeline, nekog konstruktivnog elementa cjeline. Ne zalazeći dublje u suštinu te ideje, može se konstatovati da u ovom slučaju postoji osnovna nelogičnost između termina "blok periodizacija" i njegovog misaonog određenja - pojma (Koprivica i Ćosić, 2011).

2. Kritikujući klasičnu teoriju periodizacije, Verhošanski i Isurin, vrlo rijetko citiraju Matvejeva i ne analiziraju njegove teorijske postavke, već ih slobodno tumače. To je očigledno u knjizi Issurina (2009) kada postulate klasične periodizacije daje u tabeli pod nazivom "Opšte karakteristike periodizacije treninga prema tradicionalnom pristupu" (Матвеев, 1981), ali u literaturi nema tog rada. Pored toga, Issurin izlaže grafikone godišnjeg ciklusa sa jednim, sa dva i sa tri makrociklusa koje je Matvejev objavio daleke 1977. godine na osnovu izučavanja tadašnje sportske prakse većeg broja sportista. Верхошанский (2005) u svom najznačajnijem i najobuhvatnijem članku o problemu klasične i blok periodizacije, koristi 107 bibliografskih jedinica (od čega je 71 autocitat), a ni jedna od njih nije Matvejeva. Do koje mjere je izražen subjektivni pristup u razmatranju problematike periodizacije, najbolje ilustruje popis literature za treće poglavlje knjige Issurina (2009). Iznoseći problematiku mikrociklusa, mezociklusa i pojedinačnih treninga on ni na jednom mjestu ne pominje Matvejeva, čak ni u popisu literature. Ovo nije samo krupna metodološka greška, jer je riječ o polemici i povlačenju paralele između dva koncepta, već i nepravda prema autoru koji je prvi naučno objasnio strukturu treninga i koga u ovoj oblasti svi neizostavno citiraju.

3. Verhošanski i Isurin se isključivo pozivaju na radove svojih istomišljenika, a prećutkuju radove više autora koji su na suprotnim pozicijama. Neprihvatljivo je da u potpunosti ignorišu značajne radove vodećeg svetskog autoriteta u oblasti teorije sportskog treninga, Пцатонов-а (1998, 2008, 2009) koji se energično suprotstavio blok periodizaciji.

4. Veliki propust zagovornika blok periodizacije je što su svoju kritiku bazirali na starijim radovima Matvejeva, a prećutali sve ono što je on kasnije dopunio i izmjenio (Матвеев, 1998, 1999, 2001) u skladu sa značajnim promenama u svijetu sporta.

5. Razlika između Matvejeva i njegovih oponenata 
najbolje se može vidjeti u kritici jednog od retkih citata koje navodi Верхошанский (1998). Verhošanski optužuje Matvejeva da ne krije negativan odnos prema biološkom znanju "jer tvrdi da biološke zakonitosti ne opredjeljuju makrostrukturu treninga, već je opredjeljuju u cjelini (podvukao V. K.) zakoni, po kojima se upravlja sportskom formom". U suštini Matvejev ne negira ulogu bioloških zakonitosti, ali te zakonitosti nisu jedine i nisu nezavisne od ostalih koje utiču na upravljanje sportskom formom. Za razliku od Verhošanskog, Matvejev u svakom svom djelu ima holistički pristup, neophodan uvijek kada se radi o složenoj bio-psiho-socijalnoj prirodi čovjeka.

6. Interesantno je da se neuspjesi u praksi pripisuju klasičnoj teoriji periodizacije, bez analize koja bi pokazala kako je klasična teorija realno korišćena (Верхошанский, 2005). Velika širina, koju za raznovrsne i ne uvijek predvidive situacije u praksi, u osnovnim postavkama ima teorija Matvejeva, pokazuje da njena praktična primjena mora biti stvaralačka (П аатонов, 2009).

7. Matvejevu se prigovara mehaničko ređanje i povezivanje pojedinačnih treninga u veće cjeline - mikrocikluse koji dalje grade mezocikluse i makrocikluse. Ta primjedba nije opravdana jer je to potpuno suprotno osnovnoj ideji periodizacije. Upravo Matvejev smatra da strukturu treninga nije moguće unaprjed odrediti. Prava struktura se može vidjeti $i$ analizirati tek kada se završi neki period treninga i takmičenja. Različite strukturne cjeline moraju postojati, jer su različiti i faktori koji ih uslovljavaju. U mikrociklusu se reguliše napor i odmor, u mezociklusu se upravlja kumulativnim trenažnim efektom, a u makrociklusu se upravlja sportskom formom. Vrh sportske forme, najveći kumulativni efekat i odmoran sportista u fazi superkompenzacije najvažnijih sposobnosti, moraju biti u vrijeme najvažnijeg takmičenja. Osnovni smisao periodizacije je da se postigne najbolji rezultat na najvažnijem takmičenju u sezoni. Zato klasična teorija periodizacije traži dugotrajnu, postepenu i neforsiranu pripremu za važno takmičenje koja obuhvata niz takmičenja pripremnog karaktera. Vjerovatnoća da se uspije na najvažnijem takmičenju, ako se primjeni ovakav način rada po klasičnoj periodizaciji je oko $60-75 \%$, dok je praksa pokazala da primjenom blok periodizacije verovatnoća pada na svega 5-15\% (П^атонов, 2009). Komercijalizacija sporta je značajno uticala na kalendar takmičenja i proširila ga do mjere koja više nije racionalna (Koprivica, 2009). Odabir najvažnijih takmičenja i priprema za njih po klasičnoj periodizaciji postaje sve više faktor sportske dugovječnosti. Prema tome, blok periodizacija ne odgovara vrhunskom sportu sa više takmičenja u sezoni u kome je nekoliko njih primarno. Ako sportista po blok periodizaciji na svim takmičenjima učestvuje sa ciljem da ostvari maksimalan rezultat, onda njegova karijera ne može duže trajati.

8. Očigledna je kontradiktornost u nekim osnovnim postavkama blok periodizacije. Ako se ona odnosi isključivo na vrhunske sportiste, na potrebu da se primjeni više trenažnih blokova u kojima se razvijaju samo izabrane sposobnosti i ako je potrebno uspješno učestvovati na većem broju takmičenja tokom godine, kako je to moguće u situaciji kada takmičarski period traje i po 10 mjeseci i kada je pripremni period značajno skraćen (Koprivica, 2009a, 2009b; Koprivica \& Janković, 2010). Ne samo da nema vremena za primjenu blok periodizacije, već je nemoguće razviti i održati na visokom nivou sve sposobnosti i vještine, međusobno ih uskladiti i dovesti na takav nivo koji omogućava sportisti da bude uspješan tokom duge sezone takmičenja. Prema tome, blok periodizacija ne stvara uslove za individualne maksimume i remeti međusobno usklađivanje više sposobnosti i vještina.

9. Blok periodizacija se uglavnom bavi velikim mezocikličnim blokovima koji su "pravo oličenje pojma blok periodizacije" (Issurin, 2009). Oni imaju tri različita efekta: akumulaciju, transformaciju i realizaciju (Ibid). U odnosu na klasičnu periodizaciju, na klasične strukturne dijelove srednje veličine (mezocikluse), to nije novina, jer se zasniva na onome što je već poznato i naučno objašnjeno u teoriji treninga: rad sa povećanim opterećenjem u odnosu na ona na koja je sportista adaptiran - relativna stabilizacija promjena - kumulativni efekat prethodnog rada.

10. Primjedba da klasična teorija preporučuje vježbanje "sve po malo" $i$ istovremeni razvoj više sposobnosti nije argumentovana. Mada ovu primjedbu stalno potenciraju, ni jedan autor, pobornik blok periodizacije, ne navodi adekvatan citat iz bilo kod rada Matvejeva ili citat nekog drugog značajnog autora koji se oslanja na klasičnu teoriju. Istina je da klasična teorija preporučuje da se sve sposobnosti moraju tretirati u treningu, ali tako što se stavlja akcenat na određenu sposobnost u skladu sa specifičnostima sportske grane, individualnim karakteristikama sportiste, 
klimatskim i materijalno-tehničkim faktorima (Платонов, 2009). Posebno to treba da bude usklađeno sa mjestom treninga u sezoni i glavnim takmičenjima. Dok se neke sposobnosti razvijaju, druge se moraju održavati na potrebnom nivou. U dugom takmičarskom periodu veliki je problem da se održi nivo sposobnosti, što znači da je još manje vremena za prave razvojne programe. Zbog toga je priprema za Olimpijske igre u godini kada se igre održavaju, veoma specifična (Koprivica, 2009b). Razvoj svih sposobnosti praktično i nije moguć, jer razvoj podrazumijeva opterećenja veća od onih na koja je sportista navikao. Oporavak od treninga velikog opterećenja u kome se radi na jednoj sposobnosti traje najmanje 48 sati (Платонов, 1987, 2004). Ako bi razvijali više sposobnosti (čak ne sve!) istovremeno, to bi značilo uzastopnu primjenu više treninga sa maksimalnim i velikim opterećenjem. To protivurječi jednoj od osnovnih zakonitosti treninga koju je upravo Matvejev definisao i objasnio - valovitosti dinamike opterećenja. Osim toga i nije moguće realizovati takve treninge zbog nagomilanog opterećenja i nedovoljnog vremena za oporavak sportiste.

11. Ako se po blok periodizaciji primjeni razvoj samo jedne sposobnosti u relativno dužem periodu, onda se ukupni obim treninga mora

\section{SLIKA 1}

Rez̧idualni trenažni efekti različitih sposobnosti posle specifičnog koncentrisanog uticaja (Izvor: Иссурин i Шклар, 2002)

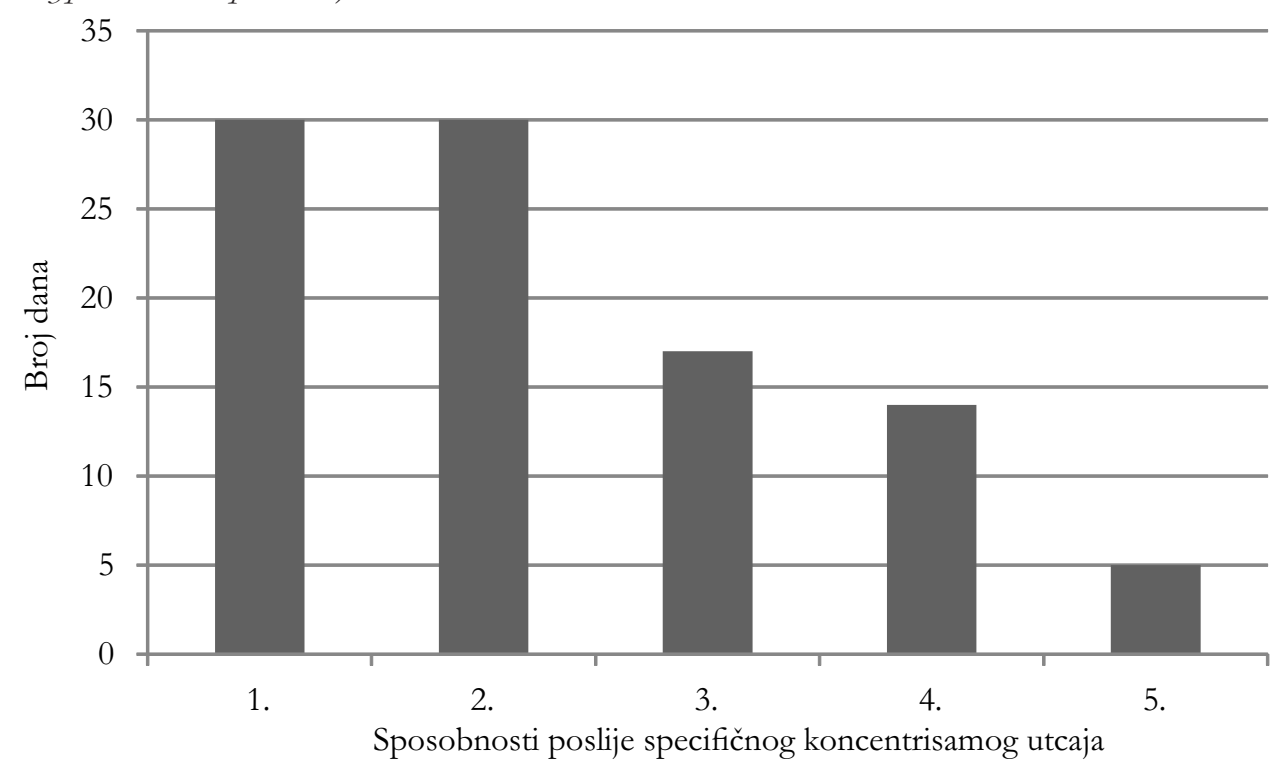

Legenda: 1. - Aerobna izdržljivost; 2. - Maksimalna sila; 3. - Anaerobna izdržljivost; 4. -

Izdržljivost u snazi; 5. - Alaktatna sposobnost.

smanjiti jer se zbog iste usmjerenosti treninga mora ostaviti više vremena za oporavak sportiste. Pored toga, zbog akumuliranog zamora, povećava se vjerovatnoća da se sportista povrijedi, a iscrpljivanje istih bioloških sistema može biti problematično sa stanovišta zdravlja sportiste. Rješenje je ili u kompleksnom radu u mikrociklusu, što blok periodizacija isključuje, ili smanjenje opterećenja radi oporavka i mirenje sa tim da se neki zadaci treninga neće riješiti.

12. Blok periodizacija je zasnovana i na tzv. Rezidualnom trenažnom efektu (Иссурин і Шкляр, 2002). Po nekim autorima koje navodi Issurin (2009) sposobnosti se održavaju određeno vrijeme (od 5 do 35 dana) nakon prestanka vježbanja i to vrijeme nije isto za sve motoričke sposobnosti (Slika 1). Ova postavka je veoma problematična, jer su neka druga istraživanja (Hargreaves, 1995; Wilmore i Costill, 2004; i drugi, citirano u Пцатонов, 2009) pokazala da se po prestanku rada već posle 1-2 nedjelje smanjuje aktivnost oksidativnih i glikolitičkih fermenata; smanjuje lokalna mišićna izdržljivost, a brzo stečene sposobnosti brzo se i gube. Biološki sistemi ranije visoko adaptirani zbog neaktivnosti su odmah podložni procesu deadaptacije. Sigurno je da se sposobnosti ne smanjuju odjednom (na primjer, dvadesetog dana), već se to odvija postepeno i diferencirano (Вовк, 2007, 2009). Poremećaj nivoa jedne sposobnosti (povećanje 
ili smanjenje) mijenja usklađenost i odnose različitih motoričkih sposobnosti, naročito onih koji su velikoj međusobnoj korelaciji. To može uticati ne samo pozitivno, već i negativno na druge sposobnosti i nivo tehničko-taktičkih veština.

13. Mada se u blok periodizaciji predviđaju različiti pristupi za, po strukturi takmičarske aktivnosti, relativno jednostavnije i složenije sportske grane, primjenu u praksi otežava obiman takmičarski kalendar tokom skoro čitave godine. Dok je primjena neke vrste "blokova" donekle i moguća u cikličnim sportskim granama sa dužim pripremnim periodom, kod složenijih sportskih grana (npr. sportske igre, borilačke sportske grane) to nije moguće.

\section{ZAKLJUČAK}

Svaka teorija, pa i teorija sportskog treninga, mora se stalno preispitivati u skladu sa dinamičnim promjenama u takmičenju i pripremi sportista. Pojava tzv. blok periodizacije privremeno je uzdrmala tradicionalnu teoriju treninga u segmentu periodizacije. Kritika klasične periodizacije nije dobro metodološki zasnovana i ne odgovara naučnom nivou rasprave o problemu (pozivanje na stare bibliografske izvore, na izvore koji idu u prilog blok periodizaciji, prećutkivanje svega što protivuriječi blok periodizaciji, namjerne pogrešne interpretacije...) i sa stanovišta nauke može se odbaciti zbog subjektivizma. Ideje nove periodizacije nisu zasnovane na naučnim činjenicama i njihova primjena u praksi nije moguća ukoliko se želi postići vrhunski rezultat u pravo vrijeme, na najvažnijem takmičenju, što je osnovna ideja periodizacije po klasičnoj teoriji. Prema tome, blok periodizacija je prije zabluda nego prekretnica u sportskom treningu.

\section{LITERATURA}

Issurin, V. (2009). Blok periodizacija-prekeretnica u sportskom treningu [Block periodization - a turning point in sports training]. Belgrade, RS:

Datastatus.

Иссурин, В., \& Шкляр, В. (2002). Концепция блоковой композиции в подготовке спортсменов высокого класса [Concept of block compositions in the preparation of highclass athletes]. Теория и практика физической культурьг, 5, 2-5.

Koprivica, V. (2009a). Aktuelni problemi izgradnje makrociklusa u vrhunskom sportu [Actual problems of building makrocykle in top level sport]. In B. Bokan (Ed.), Teorijski, metodološki i metodickei aspekti fizickog vaspitanja, Zbornik radova međunarodne naučne konferencije (pp. 181185). Belgrade, RS: Fakultet sporta i fizičkog vaspitanja.

Koprivica, V. (2009b). Problemi izgradnje makrociklusa u savremenom sportu [Problems in the construction of modern sports makrocykle]. In A. Sanader and N. Manojlović (Eds.), Prvi nacionalni seminar za sportske trenere Republike Srbije, Izazovi novog olimpijskog ciklusa (pp. 93-98). Belgade, RS: Republički zavod za sport.

Koprivica, V., \& Ćosić, M. (2011). Redefining some basic concepts in the theory of sports training. In S. Simović (Ed.), 2nd International Sceintific Conference Antropological aspects of Sports, Physical education and Recreation (pp. 105-109). Banja Luka, BA: Faculty of Physical Education and Sports. doi: 10.5550/SP.2.2010.35

Koprivica, V., \& Janković, A. (2010). Aktuelni problemi takmičarske sezone u vrhunskom fudbalu [Current problems in the competition season in elite soccer]. In A. Janković (Ed.), Strucni skup »Iskustva i perspektive - Svetsko prvenstvo u Juřnoafričkoj republici 2010. godine« (pp. 71-77). Belgrade, RS: Fakultet sporta i fizičkog vaspitanja.

Матвеев, А. П. (1964). Проблема периодизачии спортивной тренировки [Problem of periodization of sport practice]. Moscow, RU: Физкультура и спорт.

Матвеев, А. П. (1977). Основы спортивной тренировки [Fundamentals of sports practice]. Moscow, RU: Физкультура и спорт.

Матвеев, А. П. (1998). К Аискуссии о теории спортивной тренировки [Discussion about the theory of sports training]. Теория и практика физической культуры, 7, 55-61.

Матвеев, А. П. (1999). Основь общей теории спорта и системь подготовки спортсменов [Fundamentals of general theory of sports and athletes training system]. Kyev, UA: ОАимпийская митература.

Матвеев, А. П. (2001). Обшая теория спорта и ёе ирикладные аспекты [General theory of sport and its applications]. Moscow, RU: Советский спорт.

П^атонов, В. Н. (1987). Теория сnорma [Theory of sports]. Kyev, UA: Вища школа.

Пцатонов, В. Н. (1998). »О концепции периодизации спортивной тренировки« и развитии общей теории подготовки спортсменов [«About the concept of 
periodization of athletic training « and the development of the general theory of athletes practice]. Теория и практика физической культурь, 8, 23-26, 39-46.

Платонов, В. Н. (2004). Система подготовки спортсменов в олимпийком спорте [The system of athletes practice in Olympic sports]. Kyev, UA: ОАимпийская митература.

П^атонов, В. Н. (2008). Теория периодизации пОдГОТовки спортсменов високой класификации в течение года: предпосилки, формирование, критика [Theory of periodization of top level athletes practice during the year: assumptions, formation, criticism]. Наука в олимпийском спорте. 1, 3-23.

Пкатонов, В. Н. (2009). Теория тренировки в течение года: история вопроса, состояние, Аискусии, пути модернизации [Theory of practice during the year: background, status, discussions, ways to modernize]. Теория и практика физической культуры, 9, 18-34.

Верхошанский, Ю. В. (1998а). Горизонты научной теории и методологии спортивной тренировки [Horizons of scientific theory and methodology of sports practice]. Теория $и$ практика физической культуры, 7, 41-54.

Верхошанский, Ю. В. (1998b). На пути к научной теории и методологии спортивной тренировки [On the way to a scientific theory and methodology of sports practice]. Теория $u$ практика физической культурьг, 2, 2-42.

Верхошанский, Ю. В. (2005). Теория и метоАОАогия спортивной поАГОтовки: блоковая система тренировки спортсменов высокого класса [Theory and methodology of sports practice: block training system top level athletes]. Теория и практика физической культурь, 4, 2-14.

Вовк, С. И. (2007). Аиалектика спортивной тренировки [Dialectics of sports practice]. Moscow, RU: Физическая культура.

Вовк, С. И. (2009). Аинамика ряда координационных показателей при тренировке и при прекращении тренировочного процесса [Dynamics series of coordination parameters in practice and at the termination of the practice process]. Теория и практика физической культуры, 9, 75-79.

Primljeno: 11. novembra 2012. godine Izmjene primljene: 18. decembra 2012. godine Odobreno: 18. decembra 2012. godine

Korespondencija: Dr Vladimir Koprivica Fakultet sporta i fizičkog vaspitanja Blagoja Parovića 156 11030 Beograd Srbija Telefon: 00381113531033 E-mail: vkopriv@gmail.com 